\title{
SISTEM ANTREAN RUMAH SAKIT TERPADU DI RSUD PALABUHANRATU BERBASIS JAVA DAN MYSQL
}

\author{
Dendi Abdul Rohim ${ }^{1}$, Aswin Fitriansyah ${ }^{2}$, Achmad Sarwandianto ${ }^{3}$ \\ Program Studi Informatika, Fakultas Teknik dan Ilmu Komputer, Universitas Indraprasta PGRI \\ Jalan Raya Tengah No 80, Kelurahan Gedong, Pasar Rebo, Jakarta Timur \\ dendicious@gmail.com ${ }^{1}$, aswin.fitriyansyah@gmail.com² ${ }^{2}$ achmad12@gmail.com ${ }^{3}$
}

\begin{abstract}
Abstrak
Tujuan perancangan sistem antrian rumah sakit ini adalah membuat model antrian yang tepat dan efisien dalam usaha meningkatkan kualitas pelayanan di RSUD Palabuhan ratu. Metode penelitian dalam perancangan sistem antrian rumah sakit terpadu di RSUD Palabuhan ratu ini adalah dengan metode kualitatif yaitu mengamati secara langsung, wawancara dengan pihak terkait dan juga dengan melakukan dokumentasi untuk mendapatkan informasi yang dibutuhkan. Peneliti juga melakukan penelitian dengan membandingkan melalui referensi serta buku dan media lainnya yang memuat informasi yang dibutuhkan, menganalisa kebutuhan, perancangan, implementasi dan pengkodean, dan pengujian. Aplikasi sistem antrian rumah sakit terpadu berbasis Java dan MySQL ini dapat digunakan sebagai bahan masukan dan pertimbangan sederhana bagi pihak rumah sakit dalam mengambil kebijakan penerapan sistem antrian yang tepat dalam upaya meningkatkan mutu pelayananan pasien.
\end{abstract}

Kata Kunci : Sistem, Antrean Rumah Sakit, Java, MySQL

\section{Abstract}

The goal of the design of the hospital queue system is to make the proper and efficient queue model in the effort to improve the quality of service in RSUD Palabuhan ratu. The method of research in the design of the integrated hospital queue system in the Palabuhan ratu is a qualitative method of observing directly, interviews with related parties and also by conducting documentation to obtain Information needed. Researchers are also conducting research by comparing references and other books and media that contain information needed, analyzing needs, designing, implementation and coding, and testing. This integrated Java and MySQL-based hospital queue System application can be used as input material and simple consideration for the hospital to take the proper implementation of the queuing system in order to improve the quality of Patient service.

Keywords: Systems, Hospital Queues, Java, MySQL

\section{PENDAHULUAN}

Rumah Sakit merupakan instansi pelayanan kesehatan publik yang penting, dimana masyarakat adalah klien yang harus mendapatkan pelayanan yang baik. Menurut UU No.4 tahun 2009, Rumah sakit adalah institusi pelayanan kesehatan yang menyelenggarakan pelayanan kesehatan perorangan secara paripurna yang menyediakan pelayanan rawat inap, rawat jalan dan gawat darurat. Hampir setiap hari Rumah Sakit ramai oleh calon pasien yang ingin berobat. Namun masih banyak Rumah sakit yang masih menggunakan sistem antrean secara manual. Salah satu rumah sakit yang masih menggunakan metode antrean pasien rawat jalan manual yaitu RSUD Palabuhanratu.

Tujuan perancangan sistem antrean rumah sakit ini adalah membuat model antrean yang tepat dan efisien dalam usaha peningkatan kualitas pelayanan di RSUD Palabuhanratu. Sistem merupakan kumpulan dari unsur/elemen-elemen yang saling berkaitan/berinteraksi dan saling mempengaruhi dalam melakukan kegiatan bersama untuk mencapai suatu tujuan tertentu (Sutabri, 2012). Sistem juga merupakan kumpulan elemen-elemen saling terkait dan bekerja sama untuk memproses masukan (input) yang ditujukan kepada sistem tersebut dan mengolah masukan tersebut sampai menghasilkan keluaran (output) yang diinginkan (Subhan, 2012). Sistem antrean adalah suatu cara tertentu untuk mempertahankan pelanggan sehingga suatu organisasi selalu berusaha untuk memberikan pelayanan yang terbaik (Fridatama et al., 2010). Berhubungan dengan permasalahan 
dalam antrean, sistem antrean manual cenderung menimbulkan ketidaknyamanan pagi pengantre (Shinta \& Triyono, 2011).

Aplikasi sistem antrean rumah sakit terpadu pada RSUD Palabuhanratu ini dibangun dengan Bahasa pemrograman Java dan menggunakan database MySQL. Java adalah bahasa pemrograman komputer yang memiliki sekumpulan teknologi untuk membuat dan menjalankan perangkat lunak pada komputer yang berdiri sendiri ataupun pada lingkungan jaringan (Rosa \& Salahuddin, 2014). Hasil penelitian ini diharapkan dapat digunakan sebagai bahan masukan dan pertimbangan sederhana bagi pihak rumah sakit dalam mengambil kebijakan penerapan sistem antrean yang tepat dalam upaya meningkatkan mutu pelayanan pasien.

\section{PENELITIAN RELEVAN}

Penelitian oleh (Fridatama et al., 2010) dengan judul Rancang Bangun Sistem Layanan Antrian Rumah Sakit Berbasis Java. Tujuan penelitian ini adalah untuk mendesain serta merancang suatu sistem antrian pada rumah sakit yang diharapkan dapat memberikan kenyamanan pada pasien sehingga tidak ada keluhan dari pasien mengenai sistem antrian yang ada pada rumah sakit. Hasil dari penelitian dari hasil pengujian terlihat bahwa sistem antrian yang dibuat sudah berhasil dengan baik, dimana rata-rata waktu eksekusi yang dibutuhkan untuk registrasi sebesar 51.16 detik. Sedangkan rata - rata waktu eksekusi untuk mendapat nomor antrian via java lebih cepat 46.42 detik dibandingkan via sms dan rata - rata waktu yang diperlukan untuk koneksi server ke printer adalah 1 menit 27.47 detik. Dari hasil survey pada karyawan rumah sakit dan pasien rumah sakit dapat dikatakan bahwa sistem antrian pada rumah sakit berbasis JAVA memiliki penilaian dengan kategori bermanfaat. Hal ini dapat dilihat dari hasil persentase sebesar $85 \%$ karyawan rumah sakit dan $90 \%$ pasien rumah sakit menyatakan sistem antrian ini bermanfaat.

\section{METODE PENELITIAN}

Penelitian ini menggunakan metode penelitian Kualitatif. Metode Kualitatif adalah sebuah metode penelitian berdasarkan pada fakta dan menggunakan analisis perbandingan dengan tujuan mengadakan generalisasi empiris, menetapkan konsep, membuktikan teori, mengembangkan teori, pengumpulan dan analisis data dalam waktu yang bersamaan.

Saat berjalannya penelitian bukan hanya mencari dan mengumpulkan data, tetapi juga langsung melakukan klasifikasi terhadap data tersebut, mengolah dan menganalisa data, membangun hipotesis menjadi teori serta menulis laporan dari waktu ke waktu. Metode yang digunakan dalam pengumpulan data pada penelitian ini, di antaranya:

\section{Studi Pustaka}

Tahap ini merupakan tahap awal pengumpulan data dari sumber-sumber seperti buku, jurnal, yang berhubungan dengan masalah yang sedang dianalisis. Studi pustaka yang dilakukan berkaitan dengan analisis dan desain sistem informasi, konsep antrean, pemrograman Java dan query MySQL.

\section{Observasi}

Tahap ini merupakan tahap melakukan pengamatan langsung terhadap pengguna sistem dan pengamatan langsung terhadap sistem yang sedang berjalan di RSUD Palabuhanratu. Observasi ini dilakukan pada bagian Pendaftaran untuk mengetahui alur proses sistem antrean.

\section{Wawancara}

Pada tahap ini peneliti melakukan wawancara dengan calon pasien dan bagian pendaftaran sebagai pengguna sistem manual yang saat ini sedang berjalan untuk memperoleh keterangan mengenai alur proses antrean. Wawancara ini dilakukan pada staff Bagian Pendaftaran di RSUD Palabuhanratu.

\section{HASIL DAN PEMBAHASAN \\ Diagram Alir Data (DAD) Sistem Berjalan (Diagram Konteks dan Nol) Analisis Permasalahan Pada Sistem Berjalan}

Analisis permasalahan yang dapat peneliti simpulkan dari hasil penelitian yang dilakukan di RSUD Palabuhanratu adalah sebagai berikut : 
1. Pada saat pengambilan nomor antrean, ada kemungkinan nomor antrean habis. Jika nomor antrean yang tersedia habis, akan mengakibatkan pasien harus menunggu stok nomor antrean terlebih dahulu. Jika ini terjadi maka dapat mengurangi kenyamanan pasien yang berobat ke rumah sakit.

2. Pada saat proses pengambilan nomor antrean, pasien kemungkinan salah mengambil nomor antrean. Sehingga dapat mengakibatkan tidak teraturnya nomor antrean.

3. Pada saat pemanggilan nomor antrean, kerap terjadi human error yaitu kesalahan pemanggilan nomor antrean. Adanya human error dapat mengurangi tingkat kepuasan pasien berobat ke rumah sakit.

\section{Alternatif Penyelesaian Masalah}

Berdasarkan analisa proses yang dilakukan peneliti, ditemukan beberapa masalah. Dari masalah tersebut peneliti memiliki usulan alternatif penyelesaian masalah. Alternatif penyelesaian masalah tersebut adalah membuat sebuah sistem informasi antrean terpadu dengan menggunakan bahasa pemrograman Java dan menyimpan data antrean dalam database. Pembuatan sistem antrean terpadu ini diharapkan dapat meningkatkan mutu layanan yang berdapak pada tingkat kepuasan pasien yang berkunjung. Proses pengambilan nomor antrean yang tidak terbatas oleh stok nomor antrean karena sudah tergantikan oleh komputer. Kemungkinan pasien salah mengambil nomor antrean tidak terjadi lagi. Peneliti berharap tidak ada lagi human error yang salah memanggil nomor antrean karena adanya sistem antrean yang terintegrasi. Adapun aturan Sistem Antrean Terpadu di RSUD Palabuhanratu yang diusulkan adalah sebagai berikut :

1. Pendaftaran Pasien

a. Pasien menyerahkan formulir pendaftaran dan berkas yang wajib dilamporkan kepada Bagian Pendaftaran.

b. Bagian Pendaftaran menginput data pasien.

c. Bagian Pendaftaran mencetak kartu pasien dan menyerahkan ke pada pasien.

\section{Antrean Pasien}

a. Setiap pasien mengambil nomor antrean di dispenser antrean yang tersedia.

b. Setiap pasien wajib memegang satu nomor antrean.

c. Pasien memilih tujuan rujukan poliklinik di dispenser antrean.

d. Jika pasien belum memiliki Kartu Pasien, setelah mengambil nomor antrean di dispenser antrean harus melakukan pendaftaran terlebih dahulu.

e. Operator antrean (Bagian Pendaftaran atau Poliklinik) mengontrol jalannya antrean.

\section{Laporan}

a. Laporan data pasien dicetak oleh bagian pendaftaran ditandatangani oleh Penanggungjawab Bagian Pendaftaran dan pimpinan Bagian Tata Usaha.

b. Laporan data antrean dicetak oleh bagian poliklinik ditandatangani oleh penganggung jawab Unit Rawat Jalan dan pimpinan Bagian Pelayanan Medis.

\section{Diagram Alir Data (DAD) yang Diusulkan (Diagram Konteks dan Nol) \\ Diagram Konteks yang Diusulkan}

Berikut ini merupakan diagram konteks yang diusulkan pada sistem antrean rumah sakit terpadu di RSUD Palabuhanratu: 




Gambar 1. Diagram Konteks yang Diusulkan

\section{Diagram Nol yang Diusulkan}

Berikut ini merupakan diagram nol sistem antrean rumah sakit terpadu di RSUD Palabuhanratu yang menjelaskan proses-proses pada diagram konteks.

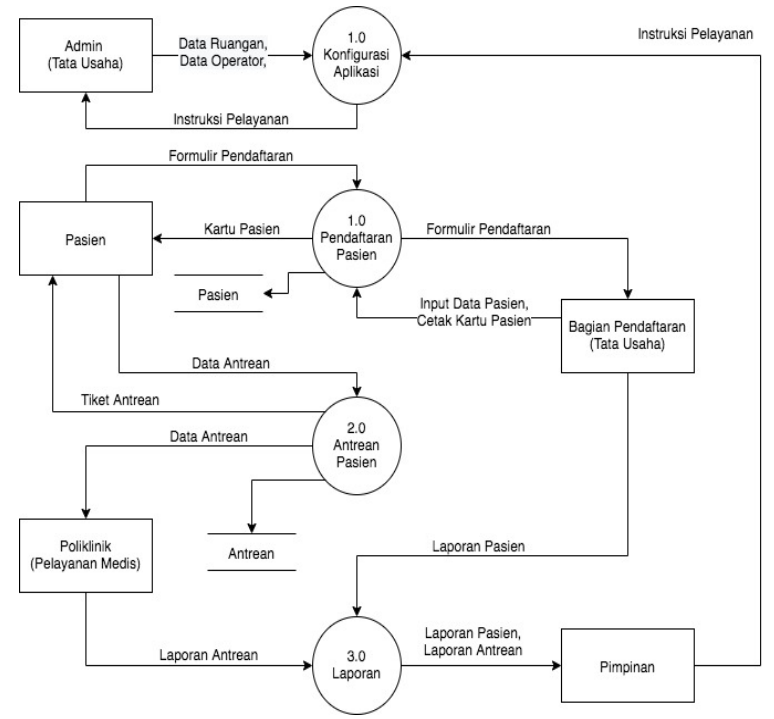

Gambar 2. Diagram Nol yang Diusulkan

\section{Flowchart Dispenser Antrean}

Adapun flowchart pengambilan tiket pada dispenser antrean yang diusulkan adalah sebagai berikut

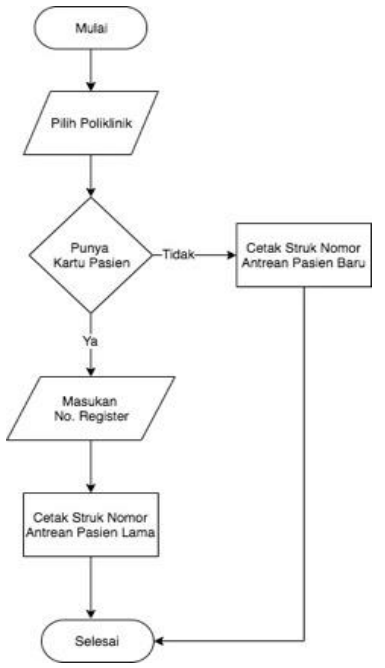

Gambar 3. Flowchart Pengambilan Tiket pada Dispenser Antrean 


\section{Normalisasi Data Sistem yang Diusulkan}

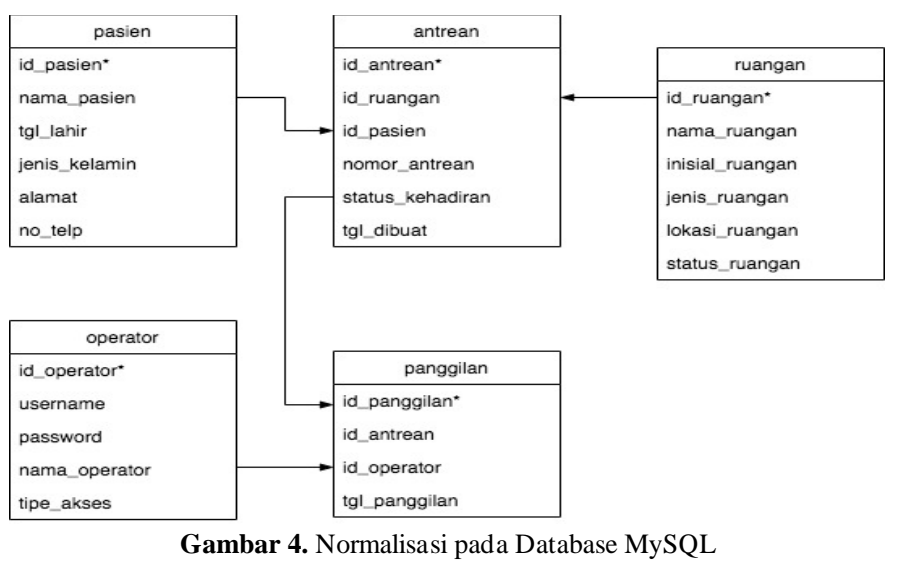

Tampilan Layar, Tampilan Format Masukan Dan Tampilan Keluaran Tampilan Menu Login

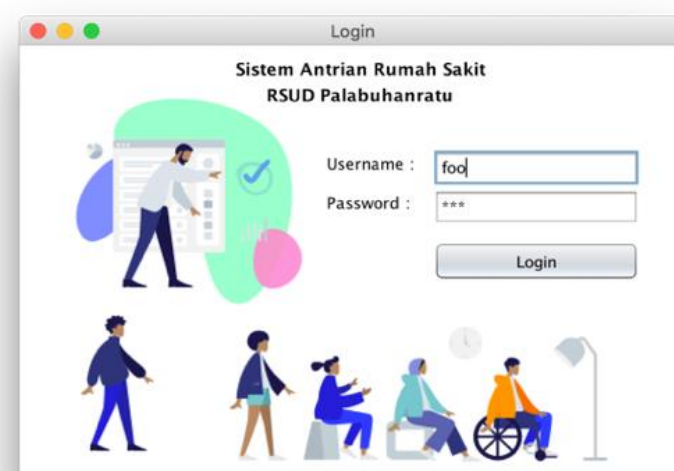

Gambar 5. Tampilan Menu Login

Pada menu login terdapat username dan password yang digunakan untuk akses ke Sistem Antrian Rumah Sakit Terpadu

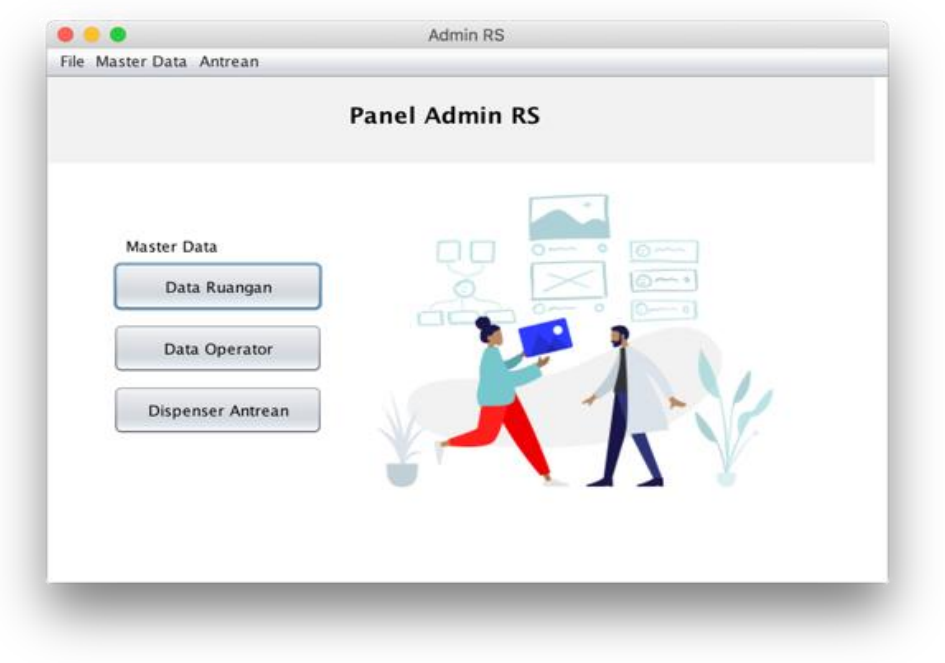

Gambar 6. Tampilan Menu Utama Admin

Pada tampilan menu utama admin terdapat beberapa menu yaitu menu file, master data dan antrian 


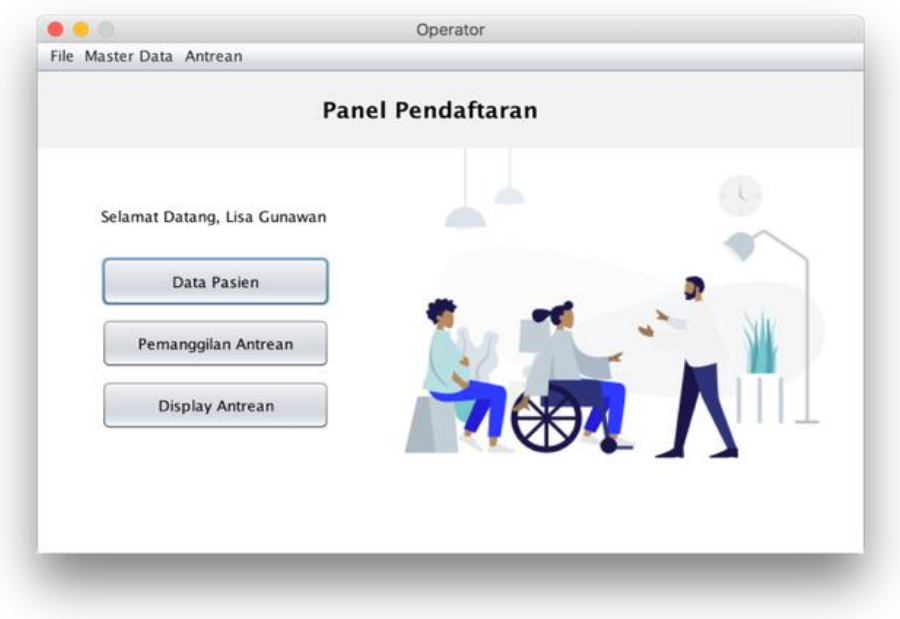

Gambar 7. Tampilan Menu Utama Operator Bagian Pendaftaran

Pada tampilan menu utama operator bagian pendaftaran terdapat beberapa menu yaitu data pasien, pemanggilan antrean dan display antrean

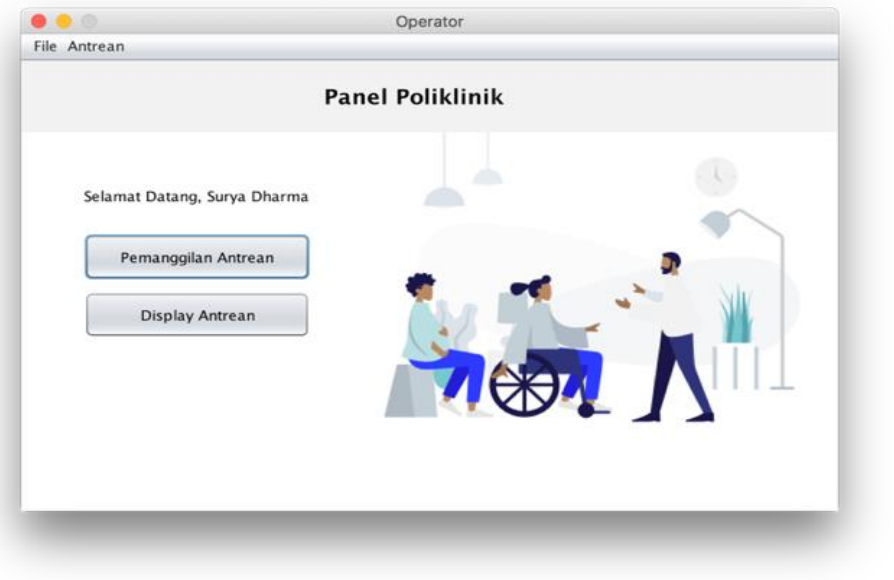

Gambar 8. Tampilan Menu Utama Poliklinik

Pada tampilan menu utama poliklinik terdapat beberapa menu yaitu pemanggilan antrian dan display antrian

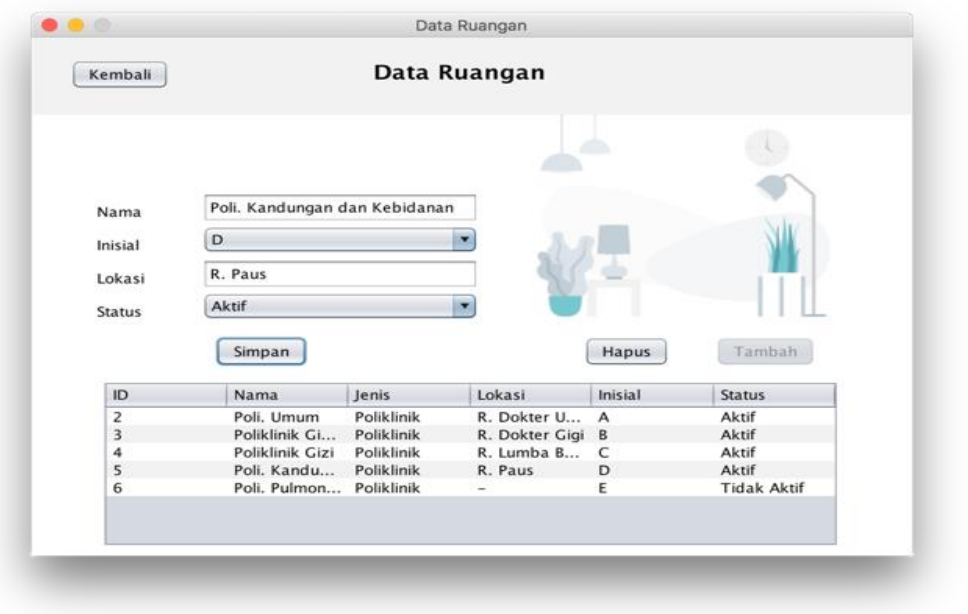

Gambar 9. Tampilan Form Data Ruangan 
Pada form data ruangan digunakan untuk menambahkan dan menyimpan data ruangan.

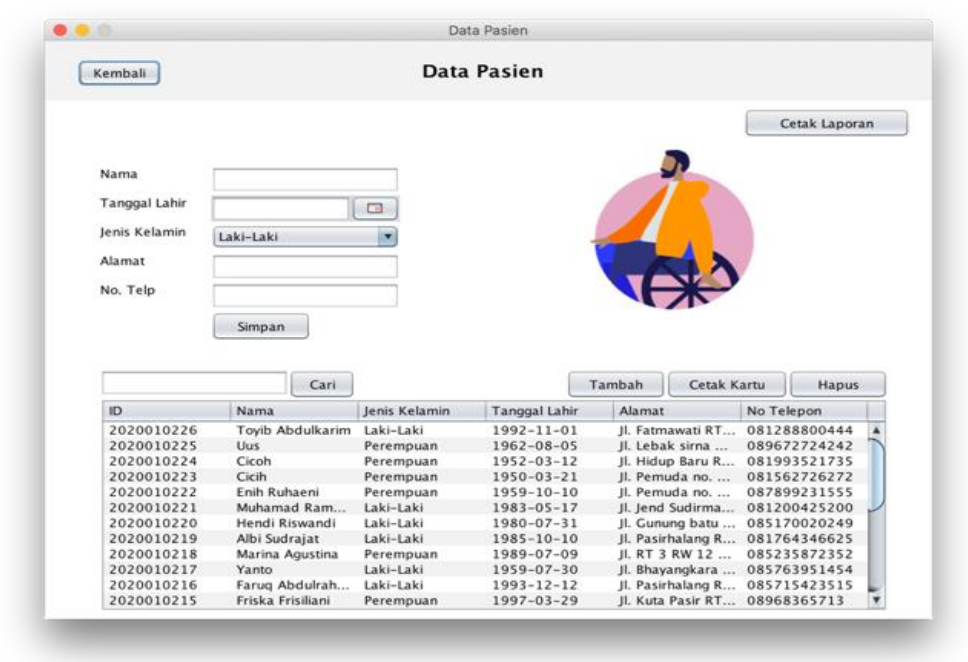

Gambar 10. Tampilan Form Data Pasien

Pada form data pasien digunakan untuk menginput dan menyimpan data pasien

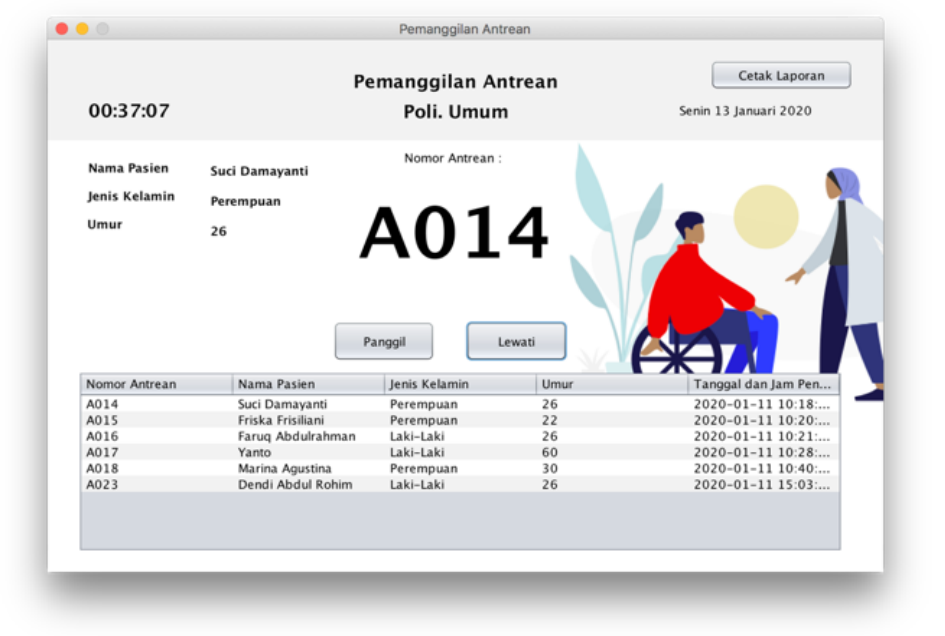

Gambar 11. Tampilan Form Pemanggilan Pasien

Pada form pemanggilan pasien digunakan untuk memanggil nomor antrean pasien

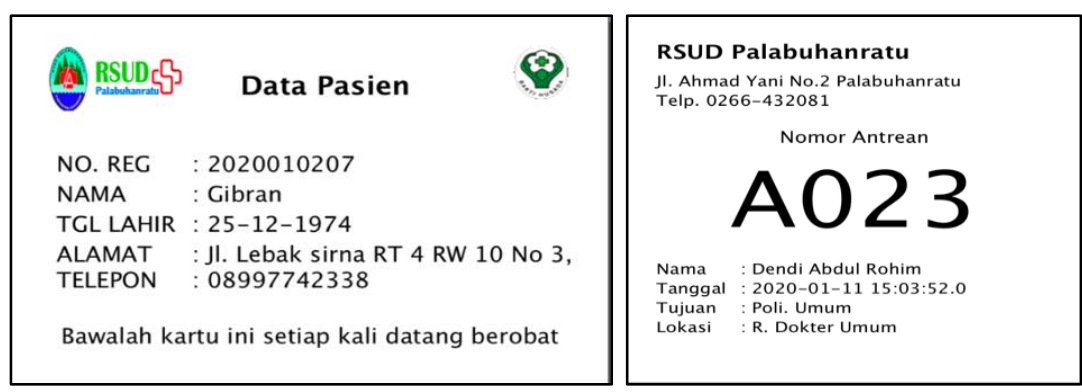

Gambar 12. Tampilan Keluaran Data Pasien dan Tiket Antrean

Gambar tersebut merupakan tampilan keluaran data pasien dan tiket antrean 


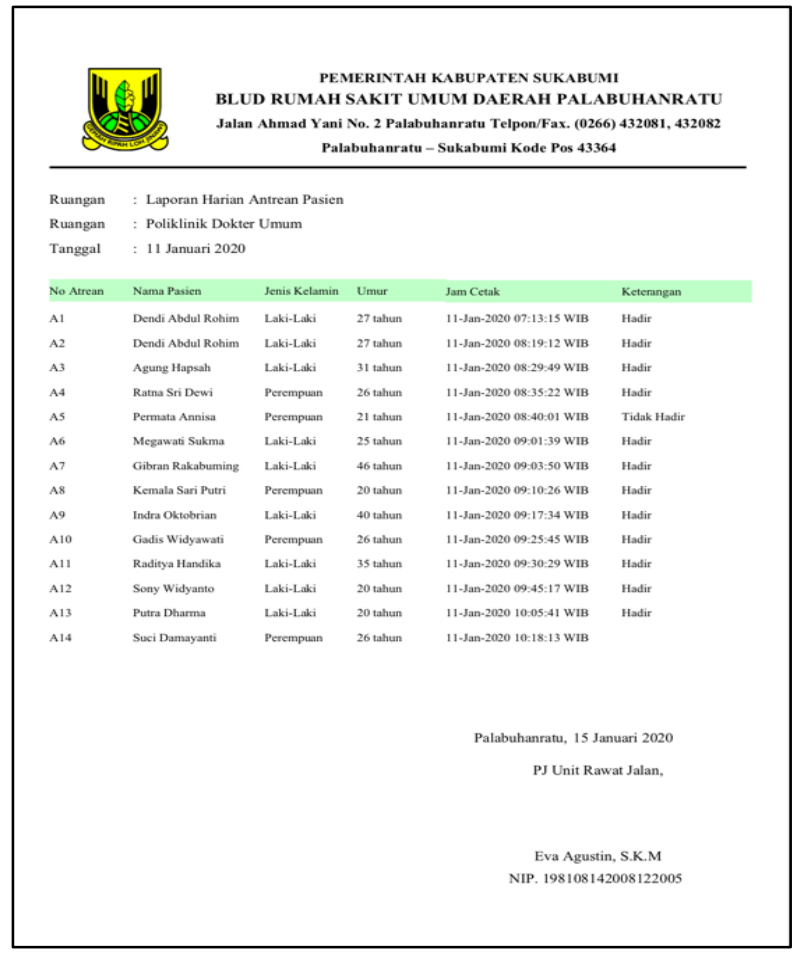

Gambar 13. Tampilan Laporan Data Antrean

Gambar tersebut merupakan tampilan laporan harian data antrean pasien

\section{SIMPULAN}

Dengan dibuatnya Sistem Antrean Rumah Sakit Terpadu di RSUD Palabuhanratu Berbasis Java dan MySQL, antrean pasien rawat jalan di RSUD Palabuhanratu memiliki alternatif pengambilan nomor antrean dan pasien tidak harus menunggu tersedianya nomor antrean yang terbatas. Pada sistem aplikasi ini, dapat mempermudah pekerjaan bagian pendaftaran dan dokter/asisten dokter dalam mengelola antrean pasien. Keberhasilan hasil perancangan ini juga membutuhkan dukungan dari pihak RSUD, terutama kedisiplinan operator dan pasien yang secara langsung memanfaatkan sistem yang telah dirancang. Dengan adanya sistem aplikasi sebagai alat bantu, peneliti dapat menyimpulkan bahwa dengan menggunakan sistem ini dapat memberikan beberapa keuntungan yaitu peningkatan kualitas pelayanan dalam hal ini proses antrean dibandingkan dengan sistem yang berjalan saat ini. Pengelolaan antrean menjadi lebih efektif, dan meningkatkan kenyamanan pasien rawat jalan saat menunggu antrean. Proses dalam pembuatan nomor antrean pasien akan lebih cepat dan akurat. Aplikasi ini pun akan memudahkan bagian pendaftaran dan poliklinik untuk mengontrol antrean yang ada dalam database.

\section{DAFTAR PUSTAKA}

Fridatama, N., Budikarso, A., \& Yuliana, M. (2010). Rancang Bangun Sistem Layanan Antrian Rumah Sakit Berbasis Java. 1-6.

Shinta, R. T., \& Triyono, G. (2011). Analisa dan Rancangan Sistem Informasi Antrian Menggunakan Biskitz CMS. Jurnal Telematika MKOM.

Sutabri, T. (2012). Konsep Sistem Informasi. Yogyakarta: Penerbit Andi.

Subhan, M. (2012). Analisa Perancangan Sistem. Jakarta: Lentera Ilmu Cendikia.

Rosa, A. S., \& Salahuddin, M. (2014). Rekayasa Perangkat Lunak : Terstruktur dan berorientasi objek. Bandung: Informatika. 